\title{
Ścisłe badania kontrolne u chorych na raka jelita grubego po leczeniu radykalnym nie są konieczne
}

\author{
Piotr Potemski
}

Aktualne rekomendacje różnych towarzystw naukowych wskazują na zasadność prowadzenia ścisłych badań kontrolnych u chorych na raka jelita grubego. Te zalecenia są oparte o wyniki metaanaliz wskazujących, że intensywne badania kontrolne wpływają na wydłużenie czasu całkowitego przeżycia. Z tego względu założenie, że poprawa rokowania ma związek z wcześniejszym wykrywaniem nawrotów i skuteczniejszym leczeniem miejscowym, wydaje się racjonalne. Jednak wykonywanie ścisłych badań kontrolnych nie wpływa na wydłużenie przeżycia u chorych z największymi czynnikami ryzyka nawrotu, takich jak osoby po radykalnej hepatektomii z powodu przerzutów raka jelita grubego do wątroby. Ponadto w metaanalizach nie wykazano wpływu na czas przeżycia zależny od nowotworu. Oznacza to, że za poprawę rokowania odpowiada zmniejszenie umieralności z innych przyczyn niż nowotwór, ale nie umieralności z powodu nowotworu. Rzeczywiście, przy okazji odbywania regularnych wizyt kontrolnych nadarza się dobra okazja do promocji prozdrowotnego trybu życia. Ukazało się wiele publikacji wskazujących na to, że modyfikacja diety, zachęcanie chorych do większej aktywności fizycznej oraz zaprzestania palenia wpływają na poprawę rokowania. Nie ma również danych pozwalających na zaproponowanie optymalnego schematu wykonywania intensywnych badań kontrolnych, a wartość poszczególnych rodzajów badań nie jest ustalona.

\section{An intensive follow-up for patients after curative resection of colorectal cancer is not necessary}

Present recommendations prepared by various scientific societies support intensive follow-up in colorectal cancer patients. These recommendations are based on the results of meta-analyses showing that intensive follow-up improves overall survival. Thus, the assumption that this survival gain could be attributable to the early detection of relapses and more effective local treatment seems to be reasonable. However, intensive follow-up does not prolong survival even in very high-risk patients such as patients after curative resection of liver metastases. Moreover, in meta-analyses, cancer-specific survival was not prolonged. It means that reduction of mortality is due to other reasons than intensive follow-up. There is a good opportunity to promote a healthy lifestyle during regular follow-up visits. There are many studies showing improvement of survival after modification of diet, promoting physical activity or cessation of smoking. There are no data allowing us to propose the optimal strategy for intensive follow-up and in addition, the value of specific diagnostic tests is not established.

NOWOTWORY Journal of Oncology 2015; 65, 5: 415-419

Słowa kluczowe: rak jelita grubego, ścisłe badania kontrolne, całkowite przeżycia, przeżycia zależne od nowotworu Key words: colorectal cancer, intensive follow-up, overall survival, cancer-specific survival

\section{Wstęp}

Aktualne międzynarodowe zalecenia towarzystw naukowych, np. European Society of Clinical Oncology (ESMO), wskazują na konieczność prowadzenia ścisłych badań kontrolnych u chorych po radykalnym leczeniu z powodu raka okrężnicy, wskazując, że jest to rekomendacja o naj- 
większym, tj. IA, stopniu wiarygodności [1]. Niestety, wiarygodność dowodów naukowych wskazujących na to, jakie badania i z jaką częstotliwością należy wykonywać, jest już znacznie mniejsza (IIB-IIIC). Wskazuje się na celowość wykonywania badania podmiotowego i przedmiotowego połączonego z oznaczaniem stężenia CEA co 3-6 miesięcy przez pierwsze 3 lata po operacji, a przez następne 2 lata co 6-12 miesięcy, kolonoskopii w 1. roku, a następnie co 3-5 lat, zaś u chorych z niekorzystnymi czynnikami rokowniczymi - komputerowej tomografii (KT) klatki piersiowej i jamy brzusznej co 6-12 mies. przez pierwsze 3 lata.

\section{Wyniki metaanaliz dotyczących znaczenia badań kontrolnych}

Taką rozbieżność pomiędzy wiarygodnością danych dotyczących wpływu wykonywania ścisłych badań kontrolnych na rokowanie a wiarygodnością zaleceń dotyczących konkretnego postępowania możemy zrozumieć dopiero wtedy, kiedy uświadomimy sobie, że powodem sformułowania takich rekomendacji były zbieżne wyniki kilku metaanaliz badań klinicznych, w których oceniano wpływ na rokowanie różnie definiowanych pod względem rodzaju i częstotliwości wykonywania ścisłych badań kontrolnych [2-5]. W tych metaanalizach wykazano, że wykonywanie regularnych badań kontrolnych w porównaniu z ich brakiem wpływa na zmniejszenie ryzyka względnego zgonu o około $25 \%$. Wydawałoby się, że logiczny ciąg wydarzeń prowadzących do takiego efektu jest oczywisty i wygląda następująco: częstsze i bardziej kompleksowe badania kontrolne $\rightarrow$ wcześniejsze wykrywanie bezobjawowych nawrotów $\rightarrow$ częstsze radykalne leczenie nawrotów $\rightarrow$ poprawa rokowania. Rzeczywiście wykazano, że nawroty, którym nie towarzyszą objawy kliniczne, wykrywane są trzykrotnie częściej u chorych poddawanych regularnym badaniom kontrolnym, i dwukrotnie częściej można było z tego powodu tych chorych operować [3]. Jednak uważniejsza analiza wyników tych prac ujawnia z pozoru zaskakujący fakt: liczby zgonów z powodu choroby nowotworowej nie różniły się! Oznacza to, że podany wyżej ciąg zdarzeń jest prawdziwy tylko w odniesieniu do jego pierwszych trzech elementów, a poprawa rokowania nie wynika ze skuteczniejszego leczenia nawrotów. Ponadto największe badania z randomizacją uwzględniane w tych metaanalizach nie wskazywały na korzyść nawet w odniesieniu do czasu całkowitego przeżycia [6, 7].

\section{W jaki sposób wykonywanie ścisłych badań kontrolnych może wpływać na rokowanie?}

Analizując możliwe przyczyny takich wyników metaanaliz, musimy pamiętać, że w czasie przeżycia zależnym od nowotworu albo inaczej związanym z nowotworem (cancer-specific survival) uwzględniane są zgony związane z progresją lub będące powikłaniami choroby nowotworowej oraz wynikające z toksyczności leczenia przeciwnowotworowe- go, natomiast w czasie całkowitego przeżycia — wszystkie zgony niezależnie od przyczyny. Z tego można wyciągnąć logiczny wniosek, że wykonywanie intensywnych badań kontrolnych wpływa przede wszystkim na zmniejszenie ryzyka zgonu z przyczyn innych niż choroba nowotworowa lub jej powikłania. Zastanówmy się teraz, na jakie inne niż nowotwór przyczyny zgonów może wpływać regularne kontrolowanie chorych? W trakcie wizyty u lekarza przeprowadzane jest badanie podmiotowe i przedmiotowe oraz zwykle zlecane są badania dodatkowe (np. CEA, badania obrazowe i inne, w zależności od zgłaszanych dolegliwości). Biorąc pod uwagę wszystkie możliwości, poprawa rokowania wynikająca z takiego postępowania może nastąpić dzięki:

- prowadzeniu profilaktyki pierwotnej i wtórnej innych nowotworów,

- propagowaniu postaw prozdrowotnych (zmiana trybu życia, diety),

- wykrywaniu i leczeniu współistniejących schorzeń, w tym innych nowotworów,

- wykrywaniu i leczeniu późnych powikłań leczenia (np. chorób układu krążenia).

Korzystny wpływ profilaktyki pierwotnej i wtórnej innych nowotworów prowadzonej przy okazji wizyt kontrolnych jest zrozumiały, ale biorąc pod uwagę względną rzadkość występowania mnogich nowotworów w ciągu kilkuletniej obserwacji, trudno spodziewać się, aby mogła ona spowodować istotne zmniejszenie umieralności. Podobnie ocenić należy znaczenie wykrywania i leczenia współistniejących schorzeń, w tym innych nowotworów oraz późnych powikłań leczenia. Najbardziej istotny wydaje się być zatem wpływ propagowania postaw prozdrowotnych. Czy jednak taka poprawa rokowania, niezależna od samego nowotworu, jest w ogóle możliwa? Spróbujmy na podstawie dostępnej literatury sprawdzić, czy wymienione czynniki mogą, a jeśli tak, to w jakim stopniu, wpłynąć na rokowanie u chorych na raka jelita grubego, u których wykonano radykalny zabieg operacyjny.

\section{Wpływ diety}

Yang i wsp. przedstawili wyniki prospektywnego badania, w którym przeanalizowali grupę niemal 2300 chorych na operacyjnego raka jelita grubego [8]. Średnia długość czasu obserwacji wyniosła 7,5 roku i w tym okresie niemal 950 osób zmarło, w tym około 400 z powodu choroby nowotworowej. Badacze ocenili wpływ zawartości wapnia w diecie, witaminy D oraz ilości spożywanych przetworów mlecznych zarówno przed rozpoznaniem, jak i po jego ustaleniu na czas całkowitego przeżycia oraz na czas przeżycia związanego z nowotworem. Dane dotyczące badanych czynników już po ustaleniu rozpoznania były dostępne dla około połowy badanych chorych. Stwierdzono, że duża zawartość wapnia w diecie po rozpoznaniu nowotworu istotnie wpływała na zmniejszenie 
ryzyka zgonu w ogóle ( $\mathrm{RR}=0,72 ; 95 \% \mathrm{Cl} 0,53-0,98)$, ale nie na zmniejszenie ryzyka zgonu z powodu nowotworu $(R R=0,59$; 95\%Cl 0,33-1,05). Istotną zależność pomiędzy zwiększonym spożyciem już po ustaleniu rozpoznania a zmniejszeniem liczby zgonów z jakiejkolwiek przyczyny znaleziono także dla mleka ( $R R=0,72 ; 95 \% C l 0,55-0,94)$, ale nie dla zawartości witaminy $\mathrm{D}$ w diecie. Wymienione czynniki, badane w okresie przed ustaleniem rozpoznania, nie miały żadnego związku z rokowaniem. Ta publikacja stanowi dowód na to, że modyfikacja diety u chorych operowanych z powodu raka jelita grubego może wpłynąć na poprawę rokowania w sposób niezależny od samego nowotworu.

U około 1200 kobiet, u których w latach 1986-2008 rozpoznano raka jelita grubego w stopniach I-III, prospektywnie oceniono jakość diety przy pomocy kwestionariusza wypełnianego nie wcześniej niż pół roku po zabiegu [9]. Chore obserwowano do roku 2010 i w tym czasie stwierdzono niemal 450 zgonów, w tym ok. 160 z powodu raka jelita grubego. Dieta określona jako,zdrowa” w porównaniu z dietą o najmniejszej wartości wpływała na istotne zmniejszenie umieralności ogólnej ( $\mathrm{HR}=0,71 ; 95 \% \mathrm{Cl} 0,52-0,98)$, mając tylko graniczny statystycznie wpływ na zmniejszenie umieralności związanej z nowotworem. Pojedynczym składnikiem diety, który miał największy wpływ na rokowanie, był alkohol — kobiety spożywające go w ilości 5-15 g dziennie miały w porównaniu z abstynentkami ryzyko zgonu z jakiejkolwiek przyczyny większe o 30\%. Nie stwierdzono takiego związku, gdy analizowano zgony związane z nowotworem.

\section{Wpływ palenia tytoniu}

U około 2500 chorych operowanych pomiędzy rokiem 1992 a 2009 z powodu wczesnego lub miejscowo zaawansowanego raka jelita grubego i obserwowanych do roku 2010 prospektywnie oceniono przy pomocy ankiet rozpowszechnienie i nasilenie zwyczaju palenia tytoniu [10]. Niemal 1100 osób zmarło, w tym około 450 z powodu nowotworu. Analiza wieloczynnikowa wykazała, że czynni palacze po rozpoznaniu w porównaniu z osobami nigdy niepalącymi mieli ponad dwukrotnie większe ryzyko zgonu z jakiejkolwiek przyczyny, jak i zgonu z powodu raka jelita grubego. Kiedy przeanalizowano wpływ palenia przed rozpoznaniem, to miało ono wpływ wyłącznie na zwiększenie umieralności ogólnej ( $R R=1,21 ; 95 \%$ 1,03-1,42). Wyniki tej pracy potwierdzają zasadniczy wniosek wypływający z opublikowanej w roku 2014 metaanalizy, wskazującej, że aktywne palenie po operacji z powodu raka jelita grubego ma niekorzystny wpływ na umieralność ogólną ( $H R=1,26$; $95 \% \mathrm{Cl} 1,15-1,37)$, a wpływ palenia przed rozpoznaniem jest dyskusyjny (HR=1,11;95\%Cl 0,93-1,33) [11].

\section{Wpływ aktywności fizycznej}

Opublikowana w roku 2014 metaanaliza wskazuje, że zwiększona aktywność fizyczna po zachorowaniu na raka jelita grubego ma wpływ na zmniejszenie zarówno ryzyka zgonu z jakiejkolwiek przyczyny $(\mathrm{RR}=0,58$; $95 \% \mathrm{Cl} 0,48-$ $-0,70)$,jakizgonu związanego z nowotworem ( $\mathrm{HR}=0,61 ; 95 \%$ $\mathrm{Cl}$ 0,40-0,92) [12]. Wykonywanie przynajmniej umiarkowanego wysiłku przez 150 minut w tygodniu po rozpoznaniu raka jelita grubego miało wpływ na zmniejszenie umieralności ogólnej o $28 \%$. Ryzyko zgonu było także istotnie mniejsze u osób, które zwiększyły swoją aktywność już po rozpoznaniu nowotworu ( $\mathrm{RR}=0,61 ; 95 \% \mathrm{Cl} 0,46-0,80)$.

Przedstawione przykłady publikacji dowodzą, że modyfikacje stylu życia (właściwa dieta, zwiększenie aktywności fizycznej, zaprzestanie palenia tytoniu), co do których chorzy po przebytej operacji z powodu raka jelita grubego mogą być zachęcani w trakcie wizyt kontrolnych, mogą mieć bardzo znaczny wpływ, przekraczający stopień zmniejszenia umieralności obserwowany w metaanalizach dotyczących znaczenia badań kontrolnych, właśnie na zmniejszenie umieralności z jakiejkolwiek przyczyny, a w mniejszym stopniu na zmniejszenie umieralności w powodu nowotworu.

\section{Propozycje modyfikowania rodzaju i częstotliwości badań kontrolnych w zależności od ryzyka nawrotu}

Ponieważ nie wiadomo, jakie badania kontrolne (poza badaniem podmiotowym i przedmiotowym) i z jaką częstotliwością należy wykonywać, niektórzy eksperci zalecają modyfikowanie ich rodzaju i rytmu w zależności od ryzyka nawrotu. Tego rodzaju uwaga znajduje się także w aktualnych rekomendacjach ESMO, w których zaleca się aby wykonywanie KT było ograniczone do grupy chorych z większym ryzykiem nawrotu (jednak nie definiując co to oznacza). Jedną z najważniejszych przyczyn takich propozycji jest próba zwiększenia efektywności kosztowej intensywnych schematów badań kontrolnych wykorzystujących regularnie wykonywane badania obrazowe. Opublikowano także propozycje bardzo rozbudowanych wersji, wskazujących jakie badania i z jaką częstotliwością powinny być wykonywane u chorych w zależności od stopnia zaawansowania raka okrężnicy (6 kategorii — od stopnia I do IIIC) [13].

Tego rodzaju podejście, poza tym że jest sposobem poprawienia efektywności kosztowej intensywnych schematów badań kontrolnych, wydaje się być intuicyjnie poprawne i sprowadza się do przyjęcia następującego rozumowania: większe ryzyko nawrotu $\rightarrow$ więcej wznów skuteczniej leczonych dzięki częstszym badaniom kontrolnym i badaniom obrazowym $\rightarrow$ poprawa rokowania. Czy jednak to rozumowanie jest prawidłowe? Dostępne dane przekonują nas szybko, że niestety nie jest. Grupą chorych na raka jelita grubego o największym ryzyku nawrotu są niewątpliwie osoby poddane radykalnej hepatektomii z powodu przerzutów do wątroby. Prawdopodobieństwo przeżycia przez nich 5 lat wynosi tylko około $40 \%$. Chorzy tacy mają bardzo duże ryzyko wznowy w wątrobie, a odpowiednio wcześnie 
wychwycony nawrót miejscowy pozwala na zastosowanie ponownego leczenia operacyjnego (nawet trzecia hepatektomia umożliwia osiągnięcie u $1 / 3$ z nich kilkuletnich przeżyć) lub dość skutecznych metod ablacyjnych, także korzystnie wpływających na rokowanie [14]. Wydawałoby się zatem, że intensywny nadzór zastosowany u chorych operowanych radykalnie $z$ powodu raka jelita grubego z przerzutami do wątroby jest szczególnie wskazany i powinien wyraźnie wpłynąć na zmniejszenie umieralności. W roku 2012 opublikowano wyniki metaanalizy obejmującej łącznie prawie 7500 takich chorych, u których porównano wpływ na rokowanie intensywnych badań kontrolnych przeprowadzanych w ciągu pierwszych 5 lat po hepatektomii oraz zwykłej obserwacji [15]. Nie stwierdzono, aby rodzaj badań kontrolnych wpływał na rokowanie - mediana czasu całkowitego przeżycia chorych poddanych intensywnemu nadzorowi była taka sama jak w grupie poddanej zwykłej obserwacji i wynosiła 40 miesięcy (odsetek chorych żyjących przynajmniej 5 lat, odpowiednio, $42 \%$ vs 38\%). Praca ta obala intuicyjną ale niepopartą faktami koncepcję uzależniania intensywności badań kontrolnych od przewidywanego ryzyka nawrotu.

\section{Które badania dodatkowe są ważne?}

Jak wspomniałem na początku, dane wskazujące na wartość poszczególnych badań dodatkowych są mało przekonywające. W 2014 roku opublikowano wyniki prospektywnego badania z randomizacją porównującego różne schematy badań wykonywanych u chorych operowanych z powodu raka jelita grubego [16]. Randomizacji poddano ponad 1200 chorych i podzielono ich na cztery grupy różniące się schematem badań kontrolnych:

1. Oznaczanie stężenia CEA co 3 miesiące przez 2 lata, potem co 6 miesięcy przez 3 lata; opcjonalnie wykonanie jeden raz KT (klatka piersiowa, jama brzuszna i miednica) między 12 a 18 miesiącem obserwacji.

2. Wykonywanie KT (klatka piersiowa, jama brzuszna i miednica) co 6 miesięcy przez 2 lata, potem co rok przez 3 lata; wykonanie kolonoskopii po 2 latach.

3. Oznaczanie stężenia CEA i wykonywanie KT jak w gr. 1 i 2; wykonanie kolonoskopii po 2 latach.

4. Brak regularnych badań, wizyty tylko wówczas, gdy pojawią się objawy kliniczne; opcjonalnie wykonanie jeden raz KT (klatka, brzuch i miednica) między 12 a 18 miesiącem obserwacji.

U wszystkich chorych przed włączeniem do badania wykonywano kolonoskopię i proponowano jej wykonanie ponownie po 5 latach. Głównym celem badania było określenie, czy odsetek chorych operowanych radykalnie z powodu nawrotu po co najmniej 3 latach obserwacji zależy od rodzaju badań kontrolnych, zaś pozostałymi celami — określenie m.in. częstości zgonów w ogóle oraz zgonów z powodu nowotworu. Po czasie obserwacji wynoszącym średnio 4,4 roku wykazano, że w pierwszych trzech grupach częściej wykonywano radykalne resekcje (odpowiednio u 6,7\%, 8,0\% i 6,6\% chorych) niż w czwartej grupie (2,2\%), ale ta różnica nie przełożyła się ani na częstość zgonów z powodu nowotworu (10,7\%, 11,7\%, 8,9\%, 9,3\%), ani na częstość zgonów z jakiejkolwiek innej przyczyny (18,7\%, $20,1 \%, 15,9 \%$ i $15,9 \%)$. Wyniki tego badania wskazują na to, że badania obrazowe nie są koniecznym elementem strategii intensywnej obserwacji po leczeniu radykalnym - tę samą rolę we wcześniejszym wykrywaniu nawrotów może pełnić badanie laboratoryjne, tzn. oznaczanie stężenia CEA. Należy podkreślić, że żaden ze sposobów prowadzenia obserwacji nie miał jednak wpływu ani na liczbę zgonów z powodu nowotworu, ani zgonów ogółem. Trzeba przy tym wspomnieć, że w badaniu tym nie przewidywano w ogóle odbywania wizyt kontrolnych u lekarza połączonych z badaniem podmiotowym i przedmiotowym, a testy do oznaczania CEA były wysyłane chorym do domu i krew była pobierana w punktach podstawowej opieki zdrowotnej. Niezależnie zatem od grupy randomizacyjnej nie było możliwości wpłynięcia na rozwinięcie postaw prozdrowotnych u chorych.

\section{Podsumowanie}

Zalecenia prowadzenia ścisłych badań kontrolnych u chorych operowanych z powodu raka jelita grubego są oparte na danych pochodzących z metaanaliz wskazujących na niewielkie zmniejszenie umieralności ogólnej, bez wpływu na częstość zgonów z powodu choroby nowotworowej. Prawdopodobnie kluczowym elementem wpływającym na poprawę rokowania jest odbywanie regularnych wizyt u lekarza, sprzyjających kształtowaniu postaw prozdrowotnych, a rodzaj i częstotliwość zlecanych badań dodatkowych, zwłaszcza obrazowych, nie mają istotnego znaczenia.

\section{Dr hab. n. med. Piotr Potemski, prof. UM}

Uniwersytet Medyczny w Łodzi

Szpital im. Mikołaja Kopernika w Łodzi

e-mail:piotr.potemski@umed.lodz.pl

Otrzymano i przyjęto do druku: 6 lipca 2015 r.

Na podstawie wystapienia podczas III Konferencji Naukowej czasopisma Nowotwory „Debaty onkologiczne”, 10-11 kwietnia 2015 roku.

\section{Piśmiennictwo}

1. Labianca R, Nordlinger B, Beretta GD i wsp. Early colon cancer: ESMO Clinical Practice Guidelines for diagnosis, treatment and follow-up. Ann Oncol 2013; 24 (Supl. 6): vi64-vi72.

2. Renehan AG, Egger M, Saunders MP i wsp. Impact on survival of intensive follow up after curative resection for colorectal cancer: systematic review and meta-analysis of randomised trials. BrMed J 2002; 324:813.

3. Tjandra JJ, Chan MK. Follow-up after curative resection of colorectal cancer: a meta-analysis. Dis Colon Rectum 2007; 50: 1783-1799.

4. Jeffery M, Hickey BE, Hider PN. Follow-up strategies for patients treated for non-metastatic colorectal cancer. Cochrane Database Syst Rev 2007 (1): CD002200 
5. Pita-Fernández S, Alhayek-Aí M., González-Martín C. Intensive follow-up strategies improve outcomes in nonmetastatic colorectal cancer patients after curative surgery: a systematic review and meta-analysis. Ann Oncol 2015; 26: 644-656.

6. Kjeldsen $\mathrm{BJ}$, Kronborg $\mathrm{O}$, Fenger $\mathrm{C}$ i wsp. A prospective randomized study of follow-up after radical surgery for colorectal cancer. Br J Surg 1997; 84: 666-669.

7. Grossmann EM, Johnson FE, Virgo KS i wsp. Follow-up of colorectal cancer patients after resection with curative intent-the GILDA trial. Surg Oncol 2004; 13: 119-124.

8. Yang B, McCullough ML, Gapstur SM i wsp. Calcium, vitamin D, dairy products, and mortality among colorectal cancer survivors: the Cancer Prevention Study-II Nutrition Cohort. J Clin Oncol 2014; 32: 2335-2343.

9. Fung TT, Kashambwa R, Sato K i wsp. Post diagnosis diet quality and colorectal cancer survival in women. PLoS One 2014; 9: e115377.

10. Yang B, Jacobs EJ, Gapstur SM i wsp. Active smoking and mortality among colorectal cancer survivors: the Cancer Prevention Study II nutrition cohort. J Clin Oncol 2015; 33: 885-893.
11. Walter V, Jansen L, Hoffmeister M i wsp. Smoking and survival of colorectal cancer patients: systematic review and meta-analysis. Ann Oncol 2014; 25: 1517-1525.

12. Schmid D, Leitzmann MF. Association between physical activity and mortality among breast cancer and colorectal cancer survivors: a systematic review and meta-analysis. Ann Oncol 2014; 25: $1293-$ $-1311$.

13. Fahy BN. Follow-up after curative resection of colorectal cancer. Ann Surg Oncol 2014; 21: 738-746.

14. Adam R, Pascal G, Azoulay D i wsp. Liver resection for colorectal metastases: the third hepatectomy. Ann Surg 2003; 238: 871-883.

15. Jones RP, Jackson R, Dunne DF i wsp. Systematic review and metaanalysis of follow-up after hepatectomy for colorectal liver metastases. Br J Surg 2012; 99: 477-486.

16. Primrose JN, Perera R, Gray A i wsp. Effect of 3 to 5 years of scheduled CEA and CT follow-up to detect recurrence of colorectal cancer: the FACS randomized clinical trial. JAMA 2014; 311: 263-270. 